\title{
Pertumbuhan dan Produksi Beberapa Varietas Padi (Oryza sativa L.) pada Berbagai Interval Irigasi
}

\section{Growth and Production of Several Rice Varieties Oryza sativa L. at Various Irrigation Intervals}

\author{
Heni Herdiyanti ${ }^{1}$, Eko Sulistyono ${ }^{2 *}$, dan Purwono ${ }^{2}$ \\ ${ }^{1}$ Program Studi Agronomi dan Hortikultura, Sekolah Pascasarjana, Institut Pertanian Bogor \\ ${ }^{2}$ Departemen Agronomi dan Hortikultura, Fakultas Pertanian, Institut Pertanian Bogor \\ (IPB University), Jl. Meranti, Kampus IPB Darmaga, Bogor 16680, Indonesia
}

Diterima 18 Juli 2021/Disetujui 26 Agustus 2021

\begin{abstract}
Increasing rice production in the dry season can be performed by improving irrigation management and use of rice varieties with high water use efficiency. This study aimed to compare the response of growth and production of six rice varieties to different irrigation intervals and obtaining the estimate of water use efficiency. This research was conducted from June to November 2019 in Indramayu Regency using a split-plot design with irrigation intervals as the main plot, namely $A=$ continuous irrigation, $B=4$-day interval, $C=8$-day interval, and $D=12$-day interval, and six rice varieties as the subplot, namely V1 = Ciherang, V2 = Mekongga, V3 = INPARI 32,V4=IPB 3S, V5 = INPAGO 11 and V6 = Situ Bagendit. The results showed that the growth and yield of rice were influenced by watering interval and variety. Longer watering intervals decreased growth and yields more markedly. IPB $3 S$ had the highest water use efficiency and INPAGO 11 had the lowest efficiency. The best irrigation interval at the time of this study was the 8-day interval, or irrigation that should be applied if the water level became $1.62 \mathrm{~cm}$ below the soil surface.
\end{abstract}

Keywords: efficiency of irrigation water use, intermittent irrigation, water level

\section{ABSTRAK}

Peningkatan produksi padi pada saat musim kemarau dapat dilakukan melalui manajemen pengairan dan penggunaan varietas efisien pengunaan air. Penelitian bertujuan untuk membandingkan pertumbuhan dan produksi enam varietas padi terhadap interval irigasi yang berbeda dan mendapatkan nilai efisiensi pemakaian air irigasi. Penelitian dilaksanakan pada bulan Juni - November 2019 di lahan sawah petani Kabupaten Indramayu, mengunakan rancangan petak terbagi. Faktor pertama sebagai petak utama adalah 4 interval irigasi yaitu $A=$ kontrol (irigasi terus menerus), $B=$ interval 4 hari, $C=$ interval 8 hari dan $D=$ interval 12 hari, serta faktor kedua sebagai anak petak yaitu 6 varietas padi yaitu V1 = Ciherang, $V 2=$ Mekongga, V3 = INPARI 32,V4 = IPB 3S, V5 = INPAGO 11 dan V6 = Situ Bagendit. Hasil penelitian menunjukkan bahwa pertumbuhan dan hasil dipengaruhi oleh interval pemberian air dan varietas. Interval pemberian air yang lebih lama menurunkan pertumbuhan dan hasil yang semakin besar. Varietas IPB $3 S$ memiliki nilai efisiensi pemakaian air irigasi tertinggi dan INPAGO 11 memiliki efisiensi terendah. Interval irigasi terbaik untuk seluruh varietas adalah interval 8 hari, atau irigasi perlu diberikan saat tinggi muka air $1.62 \mathrm{~cm}$ di bawah permukaan tanah.

Kata kunci: efisiensi pemakaian air irigasi, irigasi berselang, tinggi muka air

\section{PENDAHULUAN}

Padi (Oryza sativa L.) merupakan salah satu tanaman pangan penting bagi sebagian besar masyarakat dunia khususnya di Indonesia. Penambahan jumlah penduduk setiap tahunnya menuntut peningkatan produksi padi agar dapat mencukupi kebutuhan pangan masyarakat. Seperti diketahui bahwa beras merupakan makanan pokok masyarakat Indonesia yaitu $111.58 \mathrm{~kg}$ per kapita per tahun

\footnotetext{
* Penulis untuk korespondensi. e-mail: pengelolaanair@yahoo. com
}

(Kementerian Pertanian, 2019). Berdasarkan data BPS (2019) total produksi padi di Indonesia pada 2019 sekitar 54.60 juta ton GKG, atau mengalami penurunan sebanyak 4.60 juta ton $(7.76 \%)$ dibandingkan tahun 2018 yaitu 59.20 juta ton. Kondisi tersebut menuntut adanya upaya mencapai kestabilan produksi padi yang diharapkan dapat menjaga ketahanan dan kedaulatan pangan nasional.

Beberapa faktor dapat mempengaruhi penurunan produksi padi misalnya perubahan iklim yang menyebabkan terjadinya kekeringan di area pertanaman (Abobatta, 2019). Antisipasi yang dapat dilakukan untuk mengurangi risiko kekeringan pemilihan varietas, penanaman hingga 
pemeliharaan tanaman, pengairan dan panen (Estiningtyas et al., 2012). Perbaikan manajemen pengairan dapat melalui pemberian interval irigasi. Pemberian interval irigasi, lahan diatur pada kondisi tergenang dan kering secara bergantian sesuai dengan kondisi lahan, fase pertumbuhan dan ketersediaan jumlah air. Interval irigasi meningkatkan indeks efisiensi penggunaan air secara signifikan hingga 37.6\% dan dapat mengehemat air hingga $26.07 \%$ dibandingkan dengan irigasi terus menerus tapa mengurangi hasi produksi padi di Indonesia (Arif et al., 2013). Penelitian serupa yang dilakuakan oleh de Avila et al. (2015) juga menunjukan bahwa irigasi berselang dapat mengurangi penggunaan air $22-76 \%$, meningkatkan efisiensi peggunaan air sebesar $15 \%$ sampai 346\% tanpa mengurangi hasil produksi padi.

Risiko penurunan produksi akibat keterbatasan ketersediaan air juga dapat dikurangi melalui pengunaan varietas yang sesuai dengan kondisi lingkungan. Varietas toleran kekeringan dengan umur genjah berpotensi ditanam di daerah dengan ketersediaan air terbatas atau di daerah dengan periode hujan singkat (Suardi, 2000). Keputusan pemilihan varietas sangat penting dilakukan agar tanaman padi dapat bertahan dengan baik pada kondisi kekeringan. Penelitian ini bertujuan untuk membandingkan pertumbuhan dan hasil enam varietas padi terhadap interval irigasi yang berbeda dan mendapatkan nilai efisiensi pemakaian air irigasi.

\section{BAHAN DAN METODE}

Penelitian dilaksanakan di lahan sawah petani di Desa Sudimapir Lor, Kecamatan Balongan, Kabupaten Indramayu mulai bulan Juni-Novemer 2019. Lokasi berada pada ketinggian 1-4 mdpl, terletak pada 108.360537 BT dan -6.3964 LS. Analisa laboratorium dan pengukuran dilakukan di Laboratorium Pascapanen Departemen Agronomi dan Hortikultura, Institut Pertanian Bogor. Hasil analisis tanah menunjukkan bahwa lokasi penelitian ini memiliki pH 6.29 dengan kadar hara $0.20 \% \mathrm{~N}, 1.83 \mathrm{ppm} \mathrm{P}$ dan $0.36 \mathrm{cmol}$ kg-1 K yang masing-masing tergolong rendah, rendah, dan sedang. Benih padi yang digunakan adalah Ciherang, Mekongga, INPARI 32, IPB 3S, INPAGO 11, dan Situ Bagendit.

Penelitian ini disusun menggunakan Rancangan Petak Terbagi (Split-Plot Design). Petak utama adalah interval irigasi yaitu $\mathrm{A}=$ kontrol (irigasi terus menerus), $\mathrm{B}=$ interval 4 hari, $\mathrm{C}=$ interval 8 hari, dan $\mathrm{D}=$ interval 12 hari. Setiap kali melakukan irigasi digenangi sampai $2.5 \mathrm{~cm}$. Faktor anak petak adalah varietas yaitu padi $\mathrm{V} 1=$ Ciherang, V2 = Mekongga, V3 = INPARI 32, V4 = IPB 3S, V5 = INPAGO 11 dan V6 = Situ Bagendit. Jadi terdapat 24 kombinasi perlakuan dengan tiga ulangan sehingga didapatkan 72 unit percobaan.

Pengambilan contoh tanah dilakukan pada 3 titik sebelum penelitian dilakukan untuk menganalisa kandungan Nitrogen, Phospat dan Kalium, serta menentukan nilai kadar air tanah pada kondisi titik layu permanen, kapasitas lapang, jenuh air. Penanaman dilakukan pada umur bibit 14 hari setelah semai, dengan jarak tanam $30 \mathrm{~cm}$ x $35 \mathrm{~cm}$ dengan menggunakan 3 bibit per rumpun. Pemupukan dilakukan sebanyak dua kali. Pemupukan pertama dilakukan pada 1 minggu setelah tanam (MST) dengan menggunakan pupuk Urea $1.755 \mathrm{~kg}$, SP-36 $0.585 \mathrm{~kg}$ dan KCL $0.585 \mathrm{~kg}$ per petak utama, setara dengan $150 \mathrm{~kg} \mathrm{ha}^{-1}$ urea, $50 \mathrm{~kg} \mathrm{ha}^{-1}$ SP-36, dan $50 \mathrm{~kg} \mathrm{ha}^{-1} \mathrm{KCl}$. sedangkan pemupukan kedua dilakukan pada 4 MST menggunakan pupuk Urea $1.755 \mathrm{~kg}$ atau setara dengan $150 \mathrm{~kg} \mathrm{ha}^{-1}$ urea.

Perlakuan interval irigasi dimulai pada umur 1 MST. Sebelum aplikasi pemberian air diberikan, dilakukan terlebih dahulu pengukuran terhadap kadar air tanah mengunakan moist meter dan tinggi air tanah awal mengunakan pengaris dan water level meter. Irigasi dilakukan sampai tinggi genangan mencapai $2.5 \mathrm{~cm}$ setiap kali melakukan irigasi. Debit pompa dan lama irigasi untuk mencapai tinggi genangan $2.5 \mathrm{~cm}$ dicatat $(\mathrm{t})$. Pemanenan dilakukan saat fase masak penuh dengan ciri-ciri setiap gabah matang, berkembang penuh atau ketika padi mencapai tahap kematangan 90-100\% dan gabah berubah menjadi kuning

Tinggi tanaman (cm) dan Jumlah anakan diamati setiap minggu mulai dari 1 MST. Kandungan klorofil diukur mengunakan metode Sims dan Gamon (2002). dengan cara menghaluskan contoh daun padi kemudian disentrifuge untuk mendapatkan supernatan lalu diaduk mengunakan vortex, selanjutnya kandungan klorofil dapat diamati mengunakan spekrtofotometer. Komponen hasil yang diamati diantranya adalah Persentase jumlah gabah hampa, jumlah gabah per malai, bobot gabah kering panen per rumpun $(\mathrm{g})$, bobot gabah kering giling per hektar ( $\mathrm{g}$ ) dan bobot gabah kering giling ubinan $(\mathrm{kg})$. Bobot gabah kering giling dihitung berdasarkan 14\% kadar air gabah dari gabah kering panen. Bobot kering giling ubinan dihitung dari jumlah gabah pada ubinan $2.5 \mathrm{~cm}$ x $2.5 \mathrm{~cm}$ pada setiap anak petak. kebutuhan air per rumpun (1) dihitung dari volume air setiap kali diberikan. Efisiensi pemakaian air irigasi $\left(\mathrm{g} \mathrm{L}^{-1}\right)$ dihasilkan dari jumlah produksi suatu tanaman dengan menggunakan sejumlah air yang digunakan untuk pertumbuhan.

Data hasil pengamatan secara periodik disajikan dalam bentuk histogram dan grafik, sedangkan hasil akhir dianalisis dengan sidik ragam (Analisys of variance) menggunakan uji $\mathrm{F}$ dengan tingkat kesalahan $\alpha 5 \%$. Untuk perlakuan yang berbeda nyata diuji lebih lanjut dengan Duncan Multiple Range Test (DMRT).

\section{HASIL DAN PEMBAHASAN}

\section{Pertumbuhan Vegetatif}

Varietas Ciherang, IPB 3S, INPAGO 11 dan Situ Bagendit tidak terdapat interaksi yang nyata pada peubah tinggi tanaman, namun terdapat interaksi yang nyata pada varietas INPARI 32 dan Mekongga (Tabel 1). Tinggi tanaman pada varietas INPARI 32 pada perlakuan interval 4 hari dan interval 8 hari nyata lebih tinggi dibandingkan dengan perlakuan interval 12 hari. Secara umum tinggi tanaman yang lebih rendah pada setiap peningkatan interval irigasi diakibatkan oleh kertersediaan air yang semakin terbatas pada setiap kenaikan interval irigasi, sedangkan varietas 
Tabel 1. Interaksi antara varietas padi dan interval irigasi terhadap tinggi tanaman 6 MST dan jumlah anakan 6 MST

\begin{tabular}{lcccccccc}
\hline \multirow{2}{*}{ Varietas } & \multicolumn{3}{c}{ Tinggi tanaman $(\mathrm{cm})$} \\
\cline { 2 - 9 } & Kontrol & 4 hari & 8 hari & 12 hari & Kontrol & 4 hari & 8 hari & 12 hari \\
\hline Ciherang & $81.4 \mathrm{~cd}$ & $80.8 \mathrm{~cd}$ & $87.3 \mathrm{c}$ & $82.0 \mathrm{c}$ & $33.6 \mathrm{~b}$ & $29.4 \mathrm{bcd}$ & $29.3 \mathrm{bcd}$ & $34.4 \mathrm{~b}$ \\
Mekongga & $99.3 \mathrm{~b}$ & $82.8 \mathrm{c}$ & $82.7 \mathrm{c}$ & $83.4 \mathrm{c}$ & $32.8 \mathrm{bc}$ & $21.4 \mathrm{fghi}$ & $33.4 \mathrm{bc}$ & $29.9 \mathrm{bcd}$ \\
INPARI 32 & $81.6 \mathrm{~cd}$ & $82.3 \mathrm{c}$ & $87.2 \mathrm{c}$ & $71.5 \mathrm{~d}$ & $28.0 \mathrm{cdef}$ & $40.5 \mathrm{a}$ & $28.4 \mathrm{bcde}$ & $32.3 \mathrm{bc}$ \\
IPB 3S & $110.5 \mathrm{a}$ & $106.9 \mathrm{ab}$ & $108.4 \mathrm{ab}$ & $109.5 \mathrm{a}$ & $22.4 \mathrm{efghi}$ & $24.8 \mathrm{defghi}$ & $20.0 \mathrm{hi}$ & $20.7 \mathrm{ghi}$ \\
INPAGO 11 & $107.1 \mathrm{ab}$ & $113.5 \mathrm{a}$ & $116.5 \mathrm{a}$ & $111.6 \mathrm{a}$ & $21.8 \mathrm{fghi}$ & $18.7 \mathrm{i}$ & $24.6 \mathrm{defghi}$ & $29.6 \mathrm{bcd}$ \\
Situ Bagendit & $80.0 \mathrm{~cd}$ & $77.8 \mathrm{~cd}$ & $84.7 \mathrm{c}$ & $80.0 \mathrm{~cd}$ & $29.7 \mathrm{bcd}$ & $26.7 \mathrm{defg}$ & $30.7 \mathrm{bcd}$ & $25.4 \mathrm{defgh}$ \\
\hline
\end{tabular}

Keterangan: Angka-angka yang diikuti huruf yang sama pada kolom yang sama tidak berbeda nyata berdasarkan uji DMRT 5\%

INPARI 32 dan Mekongga keduanya merupakan varietas padi irigasi, sehingga pertumbuhanya akan maksimal apabila ketersedianan air terus tersedia, sebaliknya apabila kebutuhan air kurang mencukupi maka akan mengakibatkan terhambatnya pertumbuhan dan perkembangan tanaman. Ketersediaan air yang tidak mencukupi menyebabkan penurunan ketersediaan unsur hara dan kelarutan unsur hara dalam tanah. Dengan demikian, pengangkutan nutrisi ke jaringan tanaman juga akan lebih rendah. Air berperan penting pada proses translokasi unsur hara dari akar ke seluruh bagian tanaman, kekurangan air akan berakibat pada penurunan proses fotosintesis, sehingga mengakibatkan pertumbuhan dan perkembangan tanaman terhambat. (Sumadji dan Purbasari, 2018).

Varietas Mekongga dan INPARI 32 mengalami penurunan jumlah anak yang berbeda nyata, masing-masing pada interval 4 hari dan interval 8 hari, tetapi varietas Ciherang, IPB 3S, INPAGO 11 dan Situ Bagendit tidak mengalami penurunan yang berbeda nyata hingga interval irigasi 12 hari sekali (Tabel 1). Penurunan jumlah anakan pada ketersediaan air yang lebih rendah kemungkinan menunjukan bahwa pada kondisi tersebut tanamantidak dapat menghasilkan asimilat yang cukup optimal, sehingga laju fotosintesis menjadi terhambat. Hal ini mungkin juga terjadi karena jumlah serapan air yang sedikit untuk memproduksi asimilat sehingga pertumbuhan anakan menjadi berkurang karena upaya tanaman untuk mengoptimalkan pengunaan asimilat yang terbatas. Tanaman yang hidup pada daerah kekeringan atau mengalami stress kekeringan akan berusaha untuk mengefisiensikan penggunaan air, dengan terjadinya penurunan jumlah anakan. Penurunan jumlah anakan juga bertujuan untuk mengurangi transpirasi dan mengoptimalkan distribusi asimilat ke dalam jumlah anakan yang lebih sedikit (Effendi, 2008)

Tanaman padi dari interval irigasi 12 hari memiliki kandungan Klorofil a, Klorofil b dan Klorofil total yang berbeda nyata lebih rendah dibandingkan dengan perlakuan interval irigasi 4 hari dan interval irigasi 8 hari (Tabel 2). Kandungan klorofil yang lebih rendah pada interval irigasi 12 hari, diduga diakibatkan oleh terbatasnya ketersediaan air sehingga mempengaruhi proses metabolisme tanaman. Faktor utama dalam pembentukan klorofil salah satunya adalah unsur Nitrogen (N). Sintesis klorofil dipengaruhi oleh berbagai faktor seperti cahaya, karbohidrat, air, temperatur, faktor genetik, serapan unsur-unsur hara terutama unsur $\mathrm{N}$ (Hendriyani dan Setiari, 2009). Tanaman yang kekurangan unsur $\mathrm{N}$ akan menunjukan gelaja klorosis pada daun dan pertumbuhan yang terhambat. Penurunan kandungan hara nitrogen akan diikuti dengan penurunan kandungan klorofil pada daun (Sun et al., 2011). Pada saat tanaman mengalami kekurangan air, pengambilan unsur hara menjadi menurun. Kekeringan mengakibatkan hambatan pada aliran transport hara dengan mengurangi laju difusi, dan aliran massa oleh air ke akar. Respon fisiologis, seperti konsentrasi klorofil dalam daun, dapat digunakan sebagai indikator toleransi tanaman yang mengalami cekaman kekeringan untuk diterapkan dalam seleksi varietas tanaman yang toleran terhadap kekerinagan (Nio Song dan Banyo, 2011).

\section{Hasil Tanaman}

Varietas IPB 3S mengalami penurunan jumlah gabah per malai pada interval irigasi 12 hari, tetapi varietas Ciherang, Mekongga, INPARI 32, INPAGO 11 dan Situ Bagendit tidak mengalami penurunan hingga pemberian interval irigasi 12 hari (Tabel 3). Pada interval 12 hari varietas IPB 3S memiliki jumlah gabah per malai mencapai 224 butir per malai lebih tinggi dari varietas lainya. Jumlah ini masih sesuai dengan deskripsi jumlah gabah per malai varietas IPB 3 S mencapai \pm 223 butir (Siregar et al., 2012). Hasil penelitian ini menunjukan bahwa varietas IPB 3S memiliki kemampuan yang cukup toleran terhadap kondisi keterbatasan air meskipun pada batasan tertentu mengalami penurunan, namun masih dapat menghasilkan gabah per malai yang lebih banyak dari varietas lainnya. Berdasarkan penelitian Tubur et al. (2013) varietas IPB 3S termasuk ke dalam varietas agak toleran terhadap kekeringan. Penurunan jumlah gabah per malai, yang lebih besar seiring dengan penambahan lama pemberian irigasi menunjukan bahwa tanaman merespon terjadinya kekurangan air. Akram et al. (2013) menyatakan cekaman kekeringan pada saat inisiasi malai dapat mengganggu pembentukan jumlah gabah per malai, hal ini diakibatkan oleh penurunan yang signifikan pada kecepatan laju fotosintesis, sehingga produksi asimilat untuk pertumbuhan malai dan pengisian bulir padi menjadi berkurang, akhirnya hasil padi menurun drastis. 
Tabel 2. Kandungan klorofil a, klorofil b dan klorofi total berdasarkan interval irigasi dan varietas padi

\begin{tabular}{|c|c|c|c|}
\hline Perlakuan & Klorofil a $\left(\mathrm{mg} \mathrm{g}^{-1}\right)$ & Klorofil b $\left(\mathrm{mg} \mathrm{g}^{-1}\right)$ & Klorofil total $\left(\mathrm{mg} \mathrm{g}^{-1}\right)$ \\
\hline \multicolumn{4}{|l|}{ Interval irigasi } \\
\hline Kontrol & $2.49 \mathrm{ab}$ & $0.83 \mathrm{ab}$ & $3.12 \mathrm{ab}$ \\
\hline 4 hari & $2.79 a$ & $0.95 a$ & $3.75 \mathrm{a}$ \\
\hline 8 hari & $2.78 \mathrm{a}$ & $0.93 \mathrm{a}$ & $3.71 \mathrm{a}$ \\
\hline 12 hari & $2.34 \mathrm{~b}$ & $0.78 b$ & $3.12 b$ \\
\hline Uji F & $*$ & $*$ & * \\
\hline \multicolumn{4}{|l|}{ Varietas } \\
\hline Ciherang & $2.63 \mathrm{a}$ & $0.89 a$ & $3.52 \mathrm{a}$ \\
\hline Mekongga & $2.45 \mathrm{a}$ & $0.81 \mathrm{a}$ & $3.26 \mathrm{a}$ \\
\hline INPARI 32 & $2.79 \mathrm{a}$ & $0.95 \mathrm{a}$ & $3.74 \mathrm{a}$ \\
\hline IPB 3S & $2.64 \mathrm{a}$ & $0.88 \mathrm{a}$ & $3.53 \mathrm{a}$ \\
\hline INPAGO 11 & $2.39 \mathrm{a}$ & $0.79 a$ & $3.18 \mathrm{a}$ \\
\hline Situ Bagendit & $2.72 \mathrm{a}$ & $0.90 \mathrm{a}$ & $3.63 \mathrm{a}$ \\
\hline Uji F & tn & tn & tn \\
\hline Interaksi & tn & $\operatorname{tn}$ & tn \\
\hline
\end{tabular}

Keterangan: Angka-angka yang diikuti huruf yang sama pada kolom yang sama tidak berbeda nyata berdasarkan uji DMRT 5\%

Varitas Ciherang, Mekongga, INPARI 32, IPB 3S dan Situ Bagendit tidak mengalami kenaikan persentase jumlah gabah hampa hingga interval 12 hari sekali, sedangkan varietas INPAGO 11 mengalami kenaikan pada interval irigasi 8 hari hingga interval 12 hari (Tabel 3). Perlakuan interval irigasi diberikan hingga tanaman padi memasuki masa reproduksi, termasuk pada saat pembentukan malai dan pengisisan biji, sehingga interval irigasi 8 hari dan interval 12 hari kemungkinan telah mengalami defisit air pada saat memasuki masa tersebut, dan selanjutnya mengakibatkan tanaman padi mengalami peningkatan persentase jumlah gabah hampa. Selain faktor genetik, kekurangan air pada masa reproduksi dapat mempengaruhi hasil produksi padi. Padi merupakan tanaman yang peka terhadap kekurangan air selama fase reproduksi, yang menyebabkan penurunan tajam dalam produksi gabah. Penurunan hasil diakibatkan oleh berkurangnya pembentukan malai dan gabah hampa yang tinggi (Maisura et al., 2014).
Pemberian interval irigasi menghasikan bobot gabah kering giling (BGKG) per rumpun terbaik pada interval 8 hari dan interval 4 hari. Pertumbuhan tanaman yang baik akan meningkatkan komponen hasil, sehingga gabah yang dihasilkan juga akan lebih optimal. Interval 12 hari menghasilkan BGKG per rumpun yang lebih rendah, hal ini kemungkinan diakibatkan oleh defisit air pada masa pertumbuhan dan reproduksi, sehingga produksinya menjadi lebih rendah. Kekurangan air selama fase reproduktif menyebabkan terjadinya penurunan gabah yang dihasilkan, diikuti oleh meningkatnya gabah hampa per rumpun pada semua posisi malai (Maisura et al., 2017). Cekaman kekeringan menyebabkan penurunan produksi sebesar $32.44 \%, 41.52 \%$, dan $48.87 \%$, berturut-turut pada frekuensi irigasi 8, 12, dan 16 hari sekali (Sulistyono et al., 2012). Varietas IPB 3S menghasilkan BGKG per rumpun lebih tinggi dari varietas lainnya sebanyak $100 \mathrm{~g}$ per rumpun. Tingginya nilai BGKG pada varietas IPB 3S kemungkinan

Tabel 3. Interaksi antara varietas dan interval irigasi terhadap jumlah gabah per malai padi dan persentase jumlah gabah hampa

\begin{tabular}{|c|c|c|c|c|c|c|c|c|}
\hline \multirow{2}{*}{ Varietas } & \multicolumn{4}{|c|}{ Jumlah gabah per malai } & \multicolumn{4}{|c|}{ Jumlah gabah hampa (\%) } \\
\hline & Kontrol & 4 hari & 8 hari & 12 hari & Kontrol & 4 hari & 8 hari & 12 hari \\
\hline Ciherang & $149.5 \mathrm{def}$ & $155.2 \mathrm{def}$ & $166.6 \mathrm{cde}$ & $153.5 \mathrm{def}$ & $2.1 \mathrm{~b}$ & $1.9 \mathrm{~b}$ & $1.3 b$ & $2.4 b$ \\
\hline Mekongga & $157.2 \mathrm{def}$ & $142.8 \mathrm{def}$ & $140.5 \mathrm{def}$ & $141.2 \mathrm{def}$ & $1.6 \mathrm{~b}$ & $1.6 \mathrm{~b}$ & $2.3 b$ & $2.4 b$ \\
\hline INPARI 32 & $155.2 \mathrm{def}$ & 166.1cde & $154.1 \mathrm{def}$ & $117.9 f$ & $1.9 b$ & $1.2 \mathrm{~b}$ & $1.4 \mathrm{~b}$ & $2.5 b$ \\
\hline IPB 3S & $228.2 b$ & $275.1 \mathrm{a}$ & $271.4 \mathrm{a}$ & $224.9 b$ & $2.5 \mathrm{~b}$ & $2.8 \mathrm{~b}$ & $2.2 \mathrm{~b}$ & $2.6 b$ \\
\hline INPAGO 11 & $224.1 b$ & $229.3 b$ & $201.8 b c$ & $171.2 \mathrm{~cd}$ & $1.9 \mathrm{~b}$ & $2.7 b$ & $5.2 \mathrm{a}$ & $4.5 \mathrm{a}$ \\
\hline Situ Bagendit & $138.6 \mathrm{def}$ & $127.5 \mathrm{fe}$ & $150.5 \mathrm{def}$ & $142.0 \mathrm{def}$ & $1.7 b$ & $1.3 b$ & $1.6 \mathrm{~b}$ & $2.3 \mathrm{~b}$ \\
\hline
\end{tabular}

Keterangan: Angka-angka yang diikuti huruf yang sama tidak berbeda nyata berdasarkan uji DMRT (5\%) 
dapat diakibatkan oleh tingginya komopen hasil, diantaranya yaitu jumlah gabah per malai. Peningkatan hasil gabah akan diikuti dengan banyaknya jumlah gabah per malai (Aryana, 2009).

Varietas Mekongga dan IPB 3S menghasilkan BGKG ubinan dan BGKG per hektar yang berbeda nyata lebih tinggi dibandingkan dengan varietas INPAGO 11, tetapi tidak berbeda nyata dengan varietas Ciherang, INPARI 32 dan Situ Bagendit (Tabel 4). Berdasarkan deskripsi varietas IPB 3S memiliki potensi hasil 11.2 ton ha $^{-1}$ (Siregar et al., 2012) selain itu BGKG ubinan dan BGKG per hektar varietas IPB 3S juga memiliki korelasi positif terhadap jumlah gabah per malai. IPB 3S menghasilkan jumlah gabah per malai yang tinggi mencapai 224 butir pada interval irigasi 12 hari sehingga IPB 3S dinilai masih mampu menghasilkan produktivitas yang tinggi pada kondisi air yang lebih terbatas. Varietas Mekongga diduga karena memiliki jumlah anakan yang cukup banyak sehingga mampu menghasilkan hasil produksi yang tinggi. Hal ini sesuai dengan uji korelasi yang menunjukan adanya korelasi positif signifikan antara BGKG per hektar dan jumlah anakan total pada varietas Mekongga.

\section{Efisiensi Pemakaian Air Irigasi}

Volume air penyiraman pada interval irigasi 8 hari dan interval irigasi 12 hari lebih rendah dibandingkan dengan kontrol sebesar $50.78 \%$ dan $45.21 \%$, sedangkan kebutuhan air interval irigasi 4 hari lebih besar dibandingkan kontrol sebesar 23\%. Efisiensi pemakaian air irigasi (EPAI) adalah jumlah produksi yang dihasilkan oleh suatu tanaman dengan menggunakan sejumlah air untuk memenuhi kebutuhan air tanaman selama periode pertumbuhan. Interval irigasi 8 hari menghasilkan nilai EPAI $38.48 \mathrm{~g} \mathrm{~L}^{-1}$ lebih tinggi dibadingkan dengan perlakuan kontrol yaitu $17.42 \mathrm{~g} \mathrm{~L}^{-1}$, Interval irigasi 8 hari memiliki kebutuhan air lebih sedikit namun dapat menghasilkan BGKG per rumpun yang tinggi sehingga nilai efisiensi pengunaan air irigasi menjadi lebih tinggi dibandingkan dengan kontrol sebesar 54.74\%. Interval irigasi 4 hari menghasilkan $\mathrm{BGKG}$ per rumpun yang tinggi tidak berbeda nyata dengan interval irigasi 8 hari namun kebutuhan air interval irigasi 4 hari lebih besar dibandingkan kontrol sehingga nilai efisiensi penggunaan airnya menjadi lebih rendah. Penelitian ini sesuai dengan hasil penelitian Ashouri (2012) bahwa interval irigasi 8 hari mampu menghemat pengunaan air irigasi tanpa penurunan hasil gabah, interval irigasi 8 hari mampu menghemat $920 \mathrm{~m}^{3}$ dalam satu hektar dibandingkan dengan irigasi penggenangan terus menerus.

Varietas berpengaruh nyata terhadap EPAI. Varietas IPB 3S menghasilkan nilai EPAI lebih tinggi dibandingkan dengan varietas Ciherang, Mekongga, INPARI 32 dan Situ Bagendit, sedangkan varietas INPAGO 11 memiliki nilai EPAI yang lebih rendah dibandingkan dengan varietas lainya. IPB 3S merupakan varitas unggul baru yang memiliki sifat yang agak toleran kekeringan (Tubur et al., 2013) selain itu varietas IPB 3S juga memiliki umur panen yang genjah sehingga menjadi lebih efisien dalam penggunaan air bagi pertumbuhannya.

Tinggi muka air pada setiap pemberian interval irigasi menunjukan penurunan pada setiap penambahan perlakuan interval irigasi (Gambar 1). Berdasarkan uji regresi tinggi

Tabel 4. Hasil BGKG per rumpun, kebutuhan air per rumpun, EPAI, BGKG ubinan dan BGKG per hektar berdasarkan interval irigasi dan varietas

\begin{tabular}{|c|c|c|c|c|c|}
\hline Perlakuan & $\begin{array}{l}\text { BGKG per } \\
\text { rumpun }(\mathrm{g})\end{array}$ & $\begin{array}{l}\text { Kebutuhan air per } \\
\text { rumpun (l) }\end{array}$ & $\begin{array}{c}\text { EPAI } \\
\left(\mathrm{g} \mathrm{L}^{-1}\right)\end{array}$ & $\begin{array}{c}\text { BGKG ubinan } \\
(\mathrm{kg})\end{array}$ & $\begin{array}{c}\text { BGKG per hektar } \\
\text { (ton) }\end{array}$ \\
\hline \multicolumn{6}{|l|}{ Interval irigasi } \\
\hline Kontrol & $86.78 b c$ & $5.25 b$ & $17.41 \mathrm{c}$ & $5.64 \mathrm{a}$ & $8.97 \mathrm{a}$ \\
\hline 4 hari & $90.17 \mathrm{ab}$ & $6.83 a$ & $13.54 \mathrm{~d}$ & $5.75 \mathrm{a}$ & $9.21 \mathrm{a}$ \\
\hline 8 hari & $94.30 \mathrm{a}$ & $2.58 \mathrm{~d}$ & $38.48 \mathrm{a}$ & $6.05 \mathrm{a}$ & $9.68 \mathrm{a}$ \\
\hline 12 hari & $84.15 \mathrm{c}$ & $2.88 \mathrm{c}$ & $30.72 b$ & $6.11 \mathrm{a}$ & $9.77 \mathrm{a}$ \\
\hline Uji F & $* *$ & $* *$ & $* *$ & tn & tn \\
\hline \multicolumn{6}{|l|}{ Varietas } \\
\hline Ciherang & $88.28 b$ & $4.38 \mathrm{a}$ & $25.05 b$ & $5.91 \mathrm{ab}$ & $9.46 a b$ \\
\hline Mekongga & $88.59 b$ & $4.38 \mathrm{a}$ & $24.95 b$ & $6.27 \mathrm{a}$ & $10.03 a$ \\
\hline INPARI 32 & $88.22 b$ & $4.38 \mathrm{a}$ & $25.37 b$ & $5.79 \mathrm{ab}$ & $9.27 \mathrm{ab}$ \\
\hline IPB 3S & $100.04 \mathrm{a}$ & $4.38 \mathrm{a}$ & $27.53 a$ & $6.23 \mathrm{a}$ & $9.96 \mathrm{a}$ \\
\hline INPAGO 11 & $77.68 \mathrm{c}$ & $4.38 \mathrm{a}$ & $21.97 \mathrm{c}$ & $5.42 \mathrm{~b}$ & $8.68 b$ \\
\hline Situ Bagendit & $90.29 b$ & $4.38 \mathrm{a}$ & $25.37 b$ & $5.70 \mathrm{ab}$ & $9.05 \mathrm{ab}$ \\
\hline Uji F & $* *$ & tn & $* *$ & $*$ & $*$ \\
\hline Interaksi & $\operatorname{tn}$ & $\operatorname{tn}$ & $\operatorname{tn}$ & $\operatorname{tn}$ & $\operatorname{tn}$ \\
\hline
\end{tabular}

Keterangan: Angka-angka yang diikuti huruf yang sama pada kolom yang sama tidak berbeda nyata berdasarkan uji DMRT 5\%. EPAI $=$ Efisiensi pemakaian air irigasi; $\mathrm{BGKG}=$ Bobot gabah kering giling 
muka air pada berbagai interval irigasi dilahan sawah menunjukan perlakuan interval irigasi 8 hari merupakan interval terbaik yang dapat dipilih pada saat penelitian ini atau pemberian irigasi harus diberikan kembali apabila tinggi muka air telah mencapai $-1.62 \mathrm{~cm}$ dari permukaan tanah. Hal tersebut disebabkan pengurangan tinggi muka air interval irigasi 8 hari tidak berbeda nyata dengan perlakuan kontrol dan interval 4 hari berdasarkan uji Duncan, sehingga penambahan air menjadi lebih sedikit dan efisien serta terbukti dapat menghasilkan produksi yang tinggi.

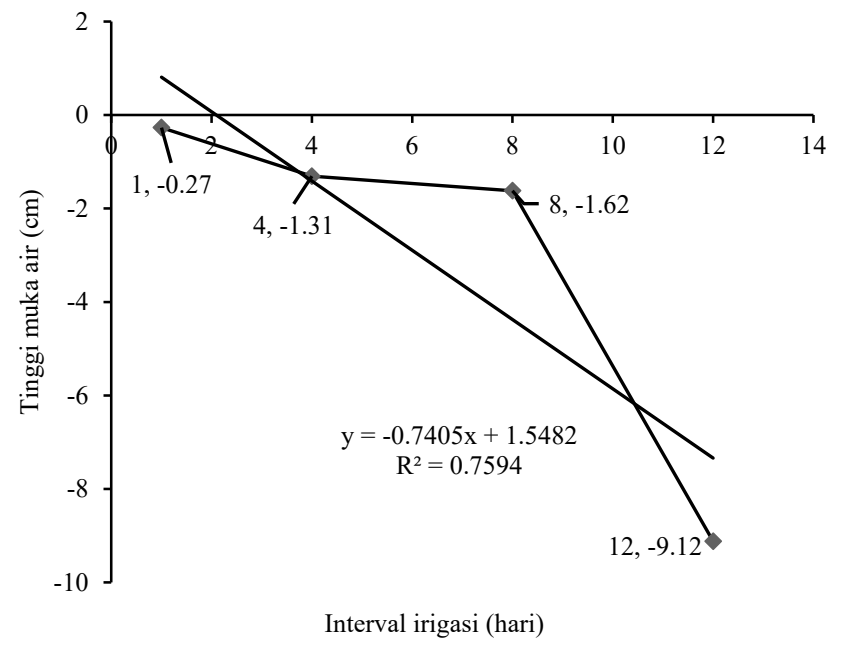

Gambar 1. Tinggi muka air pada berbagai interval irigasi di lahan sawah

\section{KESIMPULAN}

Varietas Ciherang, Mekongga, INPARI 32 dan Situ Bagendit dapat dibudidayakan hingga interval pemberian air 8 hari karena mampu menghasilkan jumlah anakan yang cukup tinggi sehingga dapat menghasilkan BGKG per rumpun, per hektar dan ubinan yang tinggi. Pada interval pemberian air lebih dari 8 hari, varietas IPB 3S memiliki nilai efisiensi pengunaan air yang tinggi yakni $27.53 \mathrm{~g} \mathrm{~L}^{-1}$, sehingga dapat mengahsilkan hasil produksi yang tinggi,. Interval irigasi terbaik adalah interval 8 hari atau irigasi perlu diberikan saat tinggi muka air $1.62 \mathrm{~cm}$ dibawah permukaan tanah

\section{DAFTAR PUSTAKA}

Abobatta, W.F. 2019. Drought adaptive mechanisms of plants - a review. Adv. Agric. Environ. 2:47-52.

Akram, H.M., A. Ali, A. Sattar, H.S.U. Rehman, A. Bibi. 2013. Impact of water deficit stress on various physiological and agronomic traits of three basmati rice (Oryza sativa L.) cultivars. J. Anim. Plant Sci. 23:1415-1423.
Arif, C., B.I. Setiawan, H.A. Sofiyuddin, L.M. Martief. 2013. Enhanced water use efficiency by intermittent irrigation for irrigated rice in Indonesia. J. Islam Perspect. Sci. Technol. Soc. 1:12-17.

Aryana, I.M. 2009. Korelasi fenotipik, genotipik dan sidik lintas serta implikasinya pada seleksi padi beras merah. Crop Agro. 2:70-78.

Ashouri, M. 2012. The effect of water saving irrigation and nitrogen fertilizer on rice production in paddy fields of Iran. Int. J. Biosci. Biochem. Bioinforma 2:56-59.

[BPS] Badan Pusat Statistik. 2019. Laju pertumbuhan penduduk penduduk menurut provinsi, 2019. http//: bps.go.id [02 April 2019].

de Avila, L.A., L.F.D. Martini, R.F. Mezzomo, J.P. Refatti, R. Campos, DM. Cezimbra, SLO. Machado, JH. Massey, R. Carlesso, E. Marchesan. 2015. Rice water use efficiency and yield under continuous and intermittent irrigation. Agron. J. 107:442-448.

Effendi, Y. 2008. Kajian resistensi beberapa varietas padi gogo (Oryza sativa L.) terhadap cekaman kekeringan. Tesis. Program Pasca Sarjana. Universitas Sebelas Maret.

Estiningtyas, W., R. Boer, I. Las, A. Buono. 2012. Identifikasi dan delineasi wilayah endemik kekeringan untuk pengelolaan risiko iklim di Kabupaten Indramayu. J. Meteorol. Geofis. 13:9-20.

Hendriyani, I., N. Setiari. 2009. Kandungan klorofil dan pertumbuhan kacang panjang (Vigna sinensis) pada tingkat penyediaan air yang berbeda. J. Sains Mat. $17: 145-150$.

Kementrian Pertanian. 2019. Konsumsi beras Indonesia tahun 2019. http://epublikasi,setjen,pertanian.go.id [3 April 2019].

Maisura, M. Chozin, I. Lubis, A. Junaedi, H. Ehara. 2014. Some physiological character responses of rice under drought condition in a paddy system. ISSAAS J. 20:104-114.

Maisura, M., M.A. Chozin, I. Lubis, A. Junaedi, H. Ehara. 2017. Laju asimilasi bersih dan laju tumbuh relatif varietas padi toleran kekeringan pada sistem sawah. J. Agrium 12:10-15.

Nio Song, A., Y. Banyo. 2011. Konsentrasi klorofil daun sebagai indikator kekurangan air pada tanaman. J. Ilm. Sains 15:166-173. 
Sims, D.A., J.A. Gamon. 2002. Relationships between leaf pigment content and spectral reflectance across a wide rang of species, leaf structures and developmental stages. Remote Sensing Environ. 81:337-354.

Siregar, I.Z., N. Khumaida, D. Noviana, M.H. Wibowo, Azizah. 2012. Varietas tanaman unggul Institut Pertanian Bogor. Direktorat Riset dan Inovasi Institut Pertanian Bogor, Bogor. ID.

Suardi, D. 2000. Kajian metode skrining padi tahan kekeringan. Bul. AgroBio 3:67-73.

Sulistyono, E., Suwarno, I. Lubis, D. Suhendar. 2012. Pengaruh frekuensi irigasi terhadap pertumbuhan dan produksi lima galur padi sawah. Agrovigor 5:1-8.
Sumadji, A.R., K. Purbasari. 2018. Indeks stomata, panjang akar dan tinggi tanaman sebagai indikator kekurangan air pada tanaman padi varietas IR64 dan Ciherang. J. AGRI-TEK. 19:82-85.

Sun, C., H. Cao, H. Shao, X. Lei, Y. Xiao. 2011. Growth and physiological responses to water and nutrient stress in oil palm. African J. Biotechnol. 10:10465-10471.

Tubur, H.W., M.A. Chozin, E. Santosa, A. Junaedi. 2013. Agronomic responses of low land rice varieties to drought periods. J. Agron. Indonesia 40:167-173. 